https://doi.org/10.22364/hssl.28.1.04

\title{
LEADERSHIP GOES BEYOND MANAGEMENT
}

\author{
Matthias Kretschmar \\ Dipl. Kfm.
}

\begin{abstract}
The perception that leadership goes beyond management is discussed in this article based upon the different perspectives on the difference between leadership and management in the literature. This article will develop a bidimensional perspective on leadership and management with an intersection between the two constructs. Key to the distinction between leadership and management are the different perspectives on change in an organisation. Leadership focuses on fundamental change whereas management is more centred upon incremental change of an organisation. In that sense, leadership goes beyond management and management is a complement to leadership in an organisation. However, it must be borne in mind that there are many overlaps between management and leadership and a boundary between change management of a leader and a manager cannot be strictly drawn. This is beneficial for managers who can add leadership skills to their managerial know-how before they will assume a leadership position in an organisation.
\end{abstract}

Keywords: Leadership, Management, Organisational Change

\section{Introduction}

There is an ongoing controversy in the literature about the difference between leadership and management and the overlap of these two terms. Some perceptions of leadership and management postulated in the literature allow the conclusion that management goes beyond leadership, others deny that there is a difference between leadership and management. This gives rise to the question if there is a permeability between management and leadership or if they are just opposing concepts.

Managers and leaders influence and give directions to people working for an organisation in order to achieve the organisation's objectives. Both initiate changes, but their approach on change management is different as their focuses vary between a predominantly transactional management and a rather transformational leadership. To some extent leadership and management are complementary as transformation cannot be initiated without transactional know-how and the controlling of transactions requires a certain knowledge about transformation. As will be seen in this article, leadership and management can therefore be regarded as bidimensional and intersecting constructs. This also implies that for the long-term 
success and even the survival of a company the transformational qualities of leadership, which go beyond management, are indispensable.

\section{Leadership}

The definition of leadership has undergone an evolutionary process over a very long time. Plato differentiated between "leading" and "execution", meaning that knowing what to do and doing it are two different things. In modern times leadership concepts were extended to exerting influence and exercising domination. ${ }^{1}$ Ever since the beginning, leadership has been regarded as the crucial factor for success (and failure). Vroom points out that "there are few problems of interest to behavioural scientists with as much apparent relevance to the problems of society as the study of leadership. The effective functioning of social systems is assumed to be dependent on the quality of their leadership. This assumption is reflected in our tendency to blame a football coach for a losing season or to credit a general for a military victory."

Leadership is defined by the respective researchers focusing on the phenomena, which are of most interest to them. It is therefore not astonishing that there are countless different definitions of leadership in literature. The perspectives of the definitions range from character traits, behaviours, influence, interaction patterns, role relationships to occupation of an administrative position. ${ }^{3}$

In Table 1 some of the most common definitions of leadership which evolved over the last decades are summarised. As can be seen, the definitions change their focus from directing, goal-oriented guidance functions towards definitions which encompass aspects of the creation of a company's culture which is meaningful for the employees and which motivates and empowers the subordinates to participate in a change process.

In analogy to Dillerup \& $\mathrm{Stoi}^{4}$ a recent definition of leadership, focusing on motivating and empowering aspects, can be summarised as the development of visions and strategies that give the company new directions. Leaders in that sense empower their subordinates to deliver outstanding performance in implementing change.

\footnotetext{
1 Nienaber (2010), p. 662.

2 Vroom (1976), p. 1527.

3 Yukl (2010), p. 20.

${ }^{4}$ Dillerup \& Stoi (2016), p. 681.
} 
Table 1. Focus of Definitions of Leadership in Literature

\begin{tabular}{|c|c|}
\hline $\begin{array}{l}\text { Representative Definitions of Leadership in literature by } \\
\text { publication date }\end{array}$ & Key Focus \\
\hline $\begin{array}{l}\text { Leadership is "the behaviour of an individual ... directing } \\
\text { the activities of a group toward a shared goal" (Hemphill \& } \\
\text { Coons (1957), p. 7) }\end{array}$ & Give direction \\
\hline $\begin{array}{l}\text { Leadership is "the influential increment over and above } \\
\text { mechanical compliance with the routine directives of } \\
\text { the organisation" (Katz \& Kahn, 1978), p. 528) }\end{array}$ & $\begin{array}{l}\text { Influence an } \\
\text { organisation }\end{array}$ \\
\hline $\begin{array}{l}\text { "Leadership is exercised when persons ... mobilize ... } \\
\text { institutional, political, psychological, and other resources so } \\
\text { as to arouse, engage, and satisfy the motives of followers" } \\
\text { (Burns (1978), p. 18) }\end{array}$ & Motivate people \\
\hline $\begin{array}{l}\text { "Leadership is realized in the process whereby one or more } \\
\text { individuals succeed in attempting to frame and define } \\
\text { the reality of others" (Smircich \& Morgan (1982), p. 258) }\end{array}$ & Frame peoples' reality \\
\hline $\begin{array}{l}\text { Leadership is "the process of influencing the activities of an } \\
\text { organized group toward goal achievement" (Rauch \& Behling } \\
\text { (1984), p. 46) }\end{array}$ & Influence people \\
\hline $\begin{array}{l}\text { "Leadership is about articulating visions, embodying values, } \\
\text { and creating the environment within which things can be } \\
\text { accomplished" (Richards \& Engle, (1986), p. 206) }\end{array}$ & $\begin{array}{l}\text { Articulate visions and } \\
\text { values, empower people }\end{array}$ \\
\hline $\begin{array}{l}\text { "Leadership is a process of giving purpose (meaningful } \\
\text { direction) to collective effort, and causing willing effort to be } \\
\text { expended to achieve purpose" (Jacobs \& Jaques (1990), p. 281) }\end{array}$ & $\begin{array}{l}\text { Give purpose and cause } \\
\text { willing efforts of people }\end{array}$ \\
\hline $\begin{array}{l}\text { Leadership "is the ability to step outside the culture ... to } \\
\text { start evolutionary change processes that are more adaptive." } \\
\text { (Schein (1992), p. 2) }\end{array}$ & $\begin{array}{l}\text { Step outside the culture } \\
\text { and initiate change } \\
\text { processes }\end{array}$ \\
\hline $\begin{array}{l}\text { "Leadership is the process of making sense of what people } \\
\text { are doing together so that people will understand and be } \\
\text { committed" (Drath \& Palus (1994), p. 4) }\end{array}$ & $\begin{array}{l}\text { Give sense to create } \\
\text { commitment }\end{array}$ \\
\hline $\begin{array}{l}\text { Leadership is "the ability of an individual to influence, } \\
\text { motivate, and enable others to contribute toward } \\
\text { the effectiveness and success of the organisation" (House \& } \\
\text { Javidan (2004), p. 15) }\end{array}$ & $\begin{array}{l}\text { Influence, motivate and } \\
\text { enable people. }\end{array}$ \\
\hline
\end{tabular}

Source: table created by the author based upon the collection of representative definitions of leadership by Yukl (2010), p. 21

\section{Management}

The primary functions of management as first described by Fayol in 1916, are planning, organising, staffing, and controlling. These functions, which help to avoid chaos in organisations, still apply to modern management objectives. Management in that sense is a quite modern concept because it only evolved with the division of work in the industrialised world. ${ }^{5}$

5 Northouse (2016), p. 13. 
"Management consists of the rational assessment of a situation and the systematic selection of goals and purposes ...; the systematic development of strategies to achieve those goals; the marshalling of the required resources; the rational design, organisation, direction, and control of the activities required to attain the selected purposes; and, finally, the motivating and rewarding of people to do the work." ${ }^{6}$ The manager can be regarded as a "problem solver"7 in complex, industrialised organisations.

Kotter points out that management is about coping with complexity in modern organisations ensuring order and consistency by planning, organising, budgeting, coordinating and monitoring. ${ }^{8}$ In other words, "management is the ability to achieve objectives with the resources available, by maintaining the organisation in operation."

\section{Different Views on Management and Leadership}

Five Perspectives on Management and Leadership

As already outlined, there is a wide range of views on the distinguishing features and the similarities between management and leadership. Simonet \& Tett worked out five different perspectives on leadership and management which have been developed in the literature: ${ }^{10}$

- The bipolar perspective is basically characterising managers and leaders as opposite sorts of people. Managers are problem solvers reacting to the past whereas leaders are inspiring, future driven and striving to initiate change.

- The unidimensional perspective does not make any difference between managers and leaders, in fact they are interchangeable. Both are accountable for motivating people, making decisions and giving direction.

- The bidimensional perspective regards leadership and management as distinct, but complementary. Both are indispensable for the organisation's success and are part of a larger whole. They are potentially intersecting to a certain degree, but they still uniquely identifiable.

- The hierarchical perspectives either see management as part (subset) of leadership or leadership as part (subset) of management.

\footnotetext{
${ }^{6}$ Levitt (1976), p. 73.

${ }^{7}$ Zaleznik (1981), p. 25.

${ }^{8}$ Kotter (2001), p. 86.

${ }^{9}$ Young \& Dulewicz (2008), p. 18.

${ }^{10} \mathrm{cf}$. in the following: Simonet \& Tett (2012), pp. 200-202.
} 


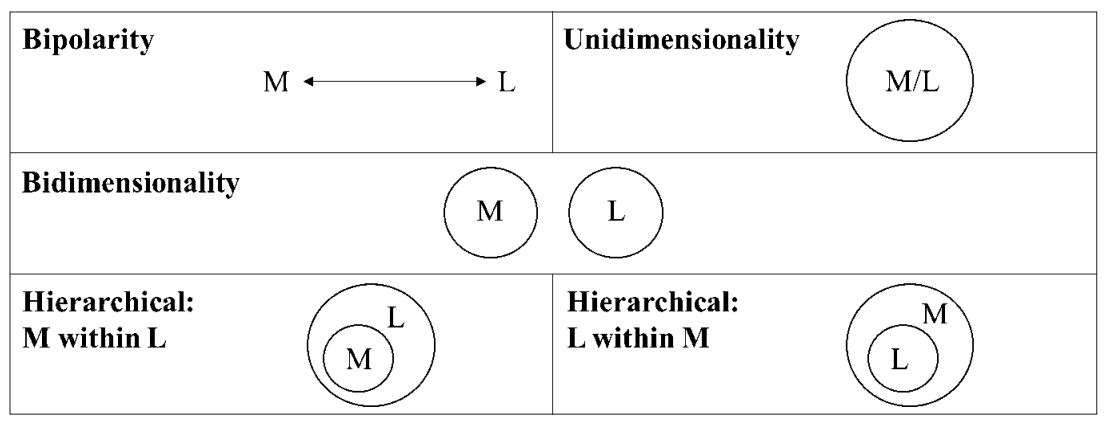

Figure 1. Five Perspectives on Management (M) and Leadership (L) Source: Simonet \& Tett (2012), p. 201

\section{Examples of Applications of the Five Perspectives in Literature}

Nienaber examined in a literature survey how the tasks or activities of management and leadership are presented in literature. For that purpose, she compiled tasks and activities which were mentioned in leadership and management literature and checked which were referred to in articles written by "management authors" and "leadership authors". The findings of her literature review show that most of the management tasks overlap with leadership tasks. Management has a few additional tasks that are not shared by leadership. ${ }^{11}$ In the sense of Simonet $\&$ Tett $^{12}$ this would be classified as a hierarchical view with leadership being a subset of management.

Toor \& Ofori ${ }^{13}$ came to a different conclusion. They analysed the views of various authors on the difference between management and leadership. They found out in their study that on the one hand there are parallels between leadership and management, and leaders and managers. But on the other hand, modern organisations should leverage on the different leadership and management qualities and skills. Toor \& Ofori state that conceptualisations of leadership and management can also be attributed to one person, like a leader with managerial capabilities or a manager with leadership qualities. ${ }^{14}$ This perspective is also reflected by Northouse saying that "when managers are involved in influencing a group to meet its goals, they are involved in leadership. When leaders are involved in planning,

\footnotetext{
${ }^{11}$ Nienaber (2010), pp. 661-675.

12 Simonet \& Tett, R. P. (2012), pp. 199-213.

13 Toor \& Ofori (2008), pp. 61-71.

${ }^{14}$ Ibid., p. 69.
} 
organising, staffing, and controlling, they are involved in management." 15 This position can be described as bidimensional according to Simonet \& Tett ${ }^{16}$ with a strong focus on the intersecting aspects between management and leadership.

Other authors make a rather bipolar distinction between the concepts of management and leadership qualifying them as quite dissimilar. "Leadership and management are two distinctive and complementary systems of action. Each has its own function and characteristic activities. Both are necessary for success in an increasingly complex and volatile business environment." 17

Kotter has worked out the key aspects that characterise the difference between leadership and management. Based on his finding that management is coping with the complexity of large organisations whereas leadership is coping with change ${ }^{18}$ the key functions of leaders and managers according to his concept can be derived as summarized in Table 2 .

Table 2. Key Differences between Management and Leadership

\begin{tabular}{|c|c|}
\hline $\begin{array}{c}\text { Management: } \\
\text { Coping with complexity }\end{array}$ & $\begin{array}{c}\text { Leadership: } \\
\text { Coping with change }\end{array}$ \\
\hline $\begin{array}{c}\text { Planning and budgeting } \\
\text { Target setting, establishment of detailed } \\
\text { plans and allocation of resources for } \\
\text { the achievement of the targets }\end{array}$ & $\begin{array}{c}\text { Setting a direction } \\
\text { Development of a long-term vision and } \\
\text { strategies for the achievement of the vision }\end{array}$ \\
\hline $\begin{array}{c}\text { Organising and staffing } \\
\text { structure to achieve the plans, and } \\
\text { monitoring of its implementation }\end{array}$ & $\begin{array}{c}\text { Aligning people } \\
\text { Commitment, creation of coalitions of } \\
\text { people who share the vision }\end{array}$ \\
\hline $\begin{array}{c}\text { Controlling and problem solving } \\
\text { Monitoring of the results in detail versus } \\
\text { the plan, organizing to solve problems }\end{array}$ & $\begin{array}{c}\text { Motivating and inspiring } \\
\text { Inspiring despite obstacles of change } \\
\text { appealing to values and emotions }\end{array}$ \\
\hline
\end{tabular}

Source: table created by the author based upon Kotter (2001), p. 86

This school of thought is often characterised by saying that "leaders are people who do the right thing; managers are people who do things

\footnotetext{
${ }^{15}$ Northouse (2007), p. 15.

${ }^{16}$ Simonet \& Tett, R. P. (2012), pp. 199-213.

${ }^{17}$ Kotter (2001), p. 85.

${ }^{18}$ Ibid., p. 86.
} 
right." ${ }^{19}$ Balancing the role of management and leadership in such an approach is critical to an organisation's success. ${ }^{20}$

\section{Synoptic perspective on management and leadership}

Adopting the bidimensional view, leadership has a strong foundation in management. The two approaches are complementary, e.g. when a leader is giving direction and inspiration with his or her visions and a manager implements and controls in his or her daily work the strategies postulated by the leader. However, there is a significant intersection between leadership and management which is not sufficiently emphasised by this concept. Managers and leaders have both also functions and qualities which are typically attributed to the other domain. One example is a manager who oversees a certain domain of a company whose CEO is a (visionary) leader. The manager is responsible for the correct realisation of the necessary steps to implement the CEO's strategy. However, in his or her domain he or she might also initiate change and postulate sub-strategies. The CEO on the other hand also has managerial tasks, controlling the overall current business of the company. So, from the point of view of the author leadership and management are complementary and at the same time intersecting. The author therefore describes the relationship between management and leadership as bidimensionality with intersection perspective on management and leadership. This is to a certain extent in compliance with the view which has been outlined by Toor $\&$ Ofori. ${ }^{21}$

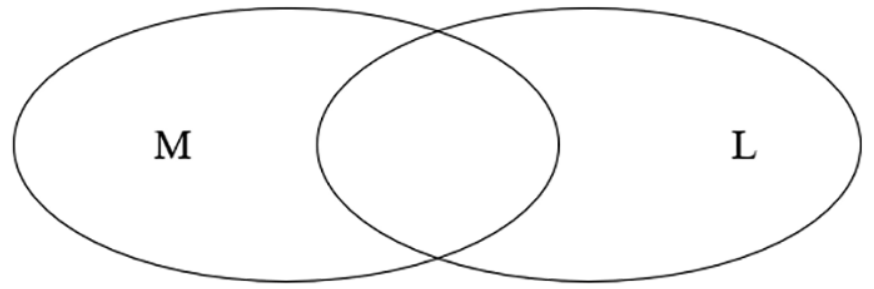

Figure 2. Bidimensionality with Intersection between Management $(\mathrm{M})$ and Leadership (L)

Source: figure created by the author, based upon the five perspectives by Simonet \& Tett (2012), p. 201

19 Bennis (2009), p. 198.

20 Algahtani (2014), p. 78.

${ }^{21}$ Toor \& Ofori (2008), pp. 61-71. 
The key indicator for the differentiation between a manager and a leader in this context is their role in organisational change which is discussed in the following.

\section{The impact of leadership and management on organisational change}

The key differentiation between people executing orders in a company and people who manage or lead is the difference in their impact on change in an organisation. Leaders and managers initiate change. Change is a precondition for the survival of nature, of societies as well as of organisations. Therefore, change can be regarded as an integral part of the DNA of every organisation. Accordingly, companies' behaviour, encompassing competitive moves, covers not only price, innovation and differentiation actions, but also first-mover advantages or the ability to compete with a repertoire of different competitive moves. ${ }^{22}$ Managers and leaders differ in the way they approach change.

\section{Typologies of Change}

There are two forms of change which can be observed in organisations. Incremental change is a continuous process of small step changes. The underlying values, attitudes and behaviours in the organisation remain unchanged. Ideally, the organisation manages this change process being a learning organisation. ${ }^{23}$ Fundamental change on the other hand leads to a strategic realignment of the company. Such a change process can only be employed successfully if it is driven by high-quality leadership and not just excellent management. ${ }^{24}$

A second dimension of change consists of reactive and anticipatory changes. Reactive changes are forced responses of the organisation to external events. Anticipatory change on the other hand is not the reaction on a contemporaneous event, but is initiated by the management in anticipation of events still to come in order to create competitive advantage. ${ }^{25}$

Combining these two dimensions in a matrix, a basic typology of change can be developed which consists of rather transactional approaches (tuning and adaptation) and rather transformational approaches (re-orientation and re-creation) (see Figure 3).

\footnotetext{
22 May \& Stahl (2017), p. 4451.

${ }^{23}$ Dillerup \& Stoi (2016), p. 707.

${ }^{24}$ Kotter (1996), p. 20.

${ }^{25}$ Nadler \& Tushman (1990), p. 79.
} 
incremental

\begin{tabular}{c|c|}
\cline { 2 - 2 } anticipatory & $\begin{array}{c}\text { tuning } \\
\text { modifications of existing processes } \\
\text { in anticipation of future events }\end{array}$ \\
\cline { 2 - 2 } reactive & $\begin{array}{c}\text { adaptation: } \\
\text { modifications of existing processes } \\
\text { as reaction on immediate demand }\end{array}$ \\
\hline
\end{tabular}

fundamental

\section{re-orientation:}

Strategic change in anticipation of future events

\section{re-creation:}

Strategic change that is prompted by immediate demand

Figure 3. Basic Typology of Change

Source: modified after: Nadler, D.A., Tushman, M. L (1990), p. 80

\section{Leadership and management in the context of change management}

Although incremental change alters an organisation permanently and is important for the success of an organisation, it is the way fundamental change is treated in an organisation which determines its survival in the long run. A manager is more focused on incremental change. He or she modifies existing processes by anticipating future events, as well as reacting to immediate demand. The leader behaves complementarily by anticipating future developments and reacting to current challenges on strategic topics. Although the boundaries between management and leadership are fluid and overlapping, the core task of the leader is fundamental change which transforms the company for the long-term survival at the marketplace. Using the typology of change, the key tasks of management and leadership can be assigned in a way as shown in figure 4 .

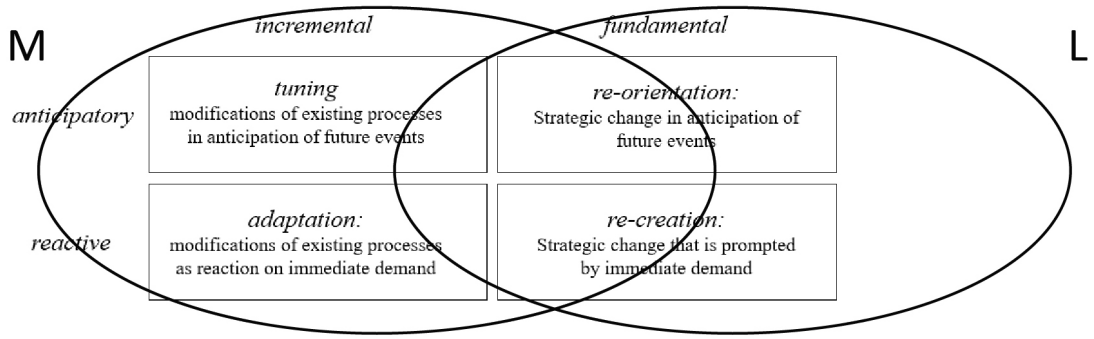

Figure 4. Management (M) and Leadership (L) Tasks with regard to of Change Source: based upon Figure 3 


\section{Conclusion}

Using the definition set out in this article, it is valid to say that leadership goes beyond management, but has a certain foundation in common, i.e. overlapping tasks and qualities which can be attributed to management and leadership. Leadership is focused on the fundamental, transformational changes in a company which is only partially the emphasis in a manager's job description. But as has been shown, the boundary between change management of a leader and a manager cannot be strictly drawn. A manager might adopt more and more leadership skills while he or she is working on a management position. He or she initiates change in the larger framework of change initiated by the leaders in the organisation. A manager who becomes a leader can rely on his or her management skills which will help him or her to be a much more efficient leader.

\section{Outlook}

This article has contributed to the discussion how management and leadership can be defined. Change management has been identified as the key differentiator between leadership and management. Leadership goes beyond management as leaders are initiating fundamental change. Further research could be conducted on the change criteria which are basically covered by leaders and the limitations of managers in theses aspects.

But, as has been worked out in this article as well, there is a significant intersection between management and leadership, which is described by the bidimensionality with intersection perspective on management and leadership. The intersection which allows a certain permeability between the two concepts could be the starting point for further studies. A question might be how and if managers can be trained and developed to become leaders and if the handling of change situations by managers helps to identify those who qualify for becoming leaders.

A systematic view on the different other supporting aspects, like e.g. the question of complexity in decisions or their motivation, which might differentiate leaders and managers, could be conducted in further research based upon a bidimensional perspective with intersection between management and leadership.

\section{REFERENCES}

Algahthani, A. (2014). Are Leadership and Management Different? A Review, Journal of Management Policies and Practices, 2(3), pp. 71-82.

Bennis, W. (2009). The essential Bennis, San Francisco, Jossey-Bass. 
Burns, J. M. (1978). Leadership, New York, Harper \& Row.

Dillerup, R. \& Stoi, R. (2016). Unternehmensführung, 5th ed., München, Vahlen.

Drath, W. R. \& Palus, C. J. (1994). Making common sense: Leadership as meaning-making in a community of practice, Greensboro, Center for Creative Leadership.

Fayol, H. (1916). General and industrial management, London, Pitman.

Hemphill, J. K. \& Coons, A. E. (1957). Development of the leader behavior description questionnaire. In: Stogdill, R. M. \& Coons, E. A. (Eds.), Leader behaviour: Its description and measurement, Columbus, Bureau of Business Research, Ohio State University, pp. 6-38.

House, R. J. \& Javidan, M. (2004). Overview of GLOBE. In: House, R. J., Hanges, P. J., Javidan, M., Dorfman, P. W., Gupta, V. (Eds.), Culture, Leadership, and Organisations, Thousand Oaks, Sage, pp. 9-28.

Jacobs, T. O. \& Jaques, E. (1990). Military executive leadership. In: Clark, K. E. \& Clark, M. B. (Eds.), Measures of leadership, West Orange, Leadership Library of America, pp. 281-295.

Katz, D. \& Kahn, R. L (1978). The social psychology of organisations, 2nd ed., New York, John Wiley.

Kotter, J. P. (1996). Leading Change, Boston, Harvard Business Press.

Kotter, J. P. (2001). What Leaders Really Do, Harvard Business Review, 81(6), pp. 85-97.

Levitt, T. (1976). Management and the 'post-industrial' society, The Public Interest 44, pp. 69-103.

May, G., Stahl, B. (2017). The significance of organisational change management for sustainable competitiveness in manufacturing: exploring the firm archetypes, International Journal of Production Research, 55(15), pp. 4.450-4.465.

Nadler, D. A., Tushman, M. L. (1990). Beyond the Charismatic Leader: Leadership and Organisational Change, California Management Review, 32(4), pp. 77-97.

Nienaber, H. (2010). Conceptualisation of management and leadership, Management Decision, 48(5), pp. 661-675.

Northouse, P. G. (2016). Leadership, 7th ed., Thousand Oaks, Sage.

Rauch, C. F. \& Behling, O. (1984). Functionalism: Basis for an Alternative Approach to the Study of Leadership. In: Hunt, J. G., Hosking, D. A, Schriesheim, C. A. \& Stewart, R. (Eds.), Leaders and Managers. International Perspectives on Managerial Behaviour and Leadership, Elmsford, Pergamon Press, pp. 45-62.

Richards, D. \& Engle, S. (1986). After the vision; Suggestions to corporate visionaries and vision champions. In: Adams, D. (Ed.), Transforming leadership, Alexandria, Miles River Press, pp. 199-214.

Schein, E. H. (1992). Organisational culture and leadership, $2^{\text {nd }}$ ed., San Francisco, JosseyBass.

Simonet, D. V. \& Tett, R. P. (2012). Five Perspectives on the Leadership-Management Relationship: A Competency-Based Evaluation and Integration, Journal of Leadership \& Organisational Studies, 20(2), pp. 199-213.

Smircich, L. \& Morgan, G. (1982). Leadership: The Management of Meaning, The Journal of Applied Behavioral Science, 18(3), pp. 257-273. 
Toor, S., Ofori, G. (2008). Leadership versus Management: How they are Different and Why, Leadership and Management in Engineering, 8(2), pp. 61-71.

Vroom, V. H. (1976). Leadership. In: Dunnette, M. D. (Ed.), Handbook of industrial and organisational psychology, Chicago, Rand McNally, pp. 1527-1551.

Young, M. \& Dulewicz, V. (2008). Similarities and Differences between Leadership and Management: High-Performance Competencies in the British Royal Navy, British Journal of Management, 19(1), pp. 17-32.

Yukl, G. (2010). Leadership in Organisations, 7th ed., Upper Saddle River, Pearson.

Zaleznik, A. (1981). Managers and Leaders: Are they different?, The Journal of Nursing Administration, 11(7), pp. 25-31. 